\title{
Retinoic acid has different effects on UCP1 expression in mouse and human adipocytes
}

\author{
Maria Murholm ${ }^{1,2 \dagger}$, Marie S Isidor ${ }^{1,2 \dagger}$, Astrid L Basse ${ }^{1,2}$, Sally Winther ${ }^{1}$, Cathrine Sørensen ${ }^{1}$, Jonas Skovgaard-Petersen? \\ Maja M Nielsen ${ }^{1}$, Aina S Hansen ${ }^{1}$, Bjørn Quistorff ${ }^{2}$ and Jacob B Hansen ${ }^{1 *}$
}

\begin{abstract}
Background: Increased adipose thermogenesis is being considered as a strategy aimed at preventing or reversing obesity. Thus, regulation of the uncoupling protein 1 (UCP1) gene in human adipocytes is of significant interest. Retinoic acid (RA), the carboxylic acid form of vitamin A, displays agonist activity toward several nuclear hormone receptors, including RA receptors (RARs) and peroxisome proliferator-activated receptor $\delta$ (PPARS). Moreover, RA is a potent positive regulator of UCP1 expression in mouse adipocytes.

Results: The effects of all-trans RA (ATRA) on UCP1 gene expression in models of mouse and human adipocyte differentiation were investigated. ATRA induced UCP1 expression in all mouse white and brown adipocytes, but inhibited or had no effect on UCP1 expression in human adipocyte cell lines and primary human white adipocytes. Experiments with various RAR agonists and a RAR antagonist in mouse cells demonstrated that the stimulatory effect of ATRA on UCP1 gene expression was indeed mediated by RARs. Consistently, a PPAR $\delta$ agonist was without effect. Moreover, the ATRA-mediated induction of UCP1 expression in mouse adipocytes was independent of PPARY coactivator-1a.
\end{abstract}

Conclusions: UCP1 expression is differently affected by ATRA in mouse and human adipocytes. ATRA induces UCP1 expression in mouse adipocytes through activation of RARs, whereas expression of UCP1 in human adipocytes is not increased by exposure to ATRA.

Keywords: Adipogenesis, ATRA, Brown adipocyte, UCP1, White adipocyte

\section{Background}

Mammals have two types of fat, white and brown adipose tissue (WAT and BAT, respectively), that carry out essentially opposite functions in whole body energy metabolism [1,2]. White adipocytes are specialized in energy storage and their content of triglyceride constitutes the largest energy reserve of the body. Contrary, brown adipocytes have a high capacity for energy dissipation through adaptive thermogenesis due to the presence of the brown adipocyte-specific uncoupling protein 1 (UCP1) in the inner membrane of the abundant mitochondria. BAT has been shown to counteract obesity and is important for rodents to defend their body temperature in response to prolonged cold exposure [1]. Brown-like adipocytes

\footnotetext{
* Correspondence: jacob.hansen@bio.ku.dk

${ }^{\dagger}$ Equal contributors

'Department of Biology, University of Copenhagen, Universitetsparken 13, DK-2100 Copenhagen $\varnothing$, Denmark

Full list of author information is available at the end of the article
}

expressing UCP1 appear in some rodent WAT depots after cold exposure or treatment with $\beta$-adrenergic agonists $[3,4]$. Recent studies have suggested a negative correlation between body mass index and the amount of active BAT in humans [5]. Strategies aiming at increasing levels of UCP1 in WAT have become of interest as reduced expression of brown adipocyte-enriched genes in WAT is associated with obesity and type 2 diabetes in humans [6-8].

Retinoic acid (RA) is a derivative of vitamin A that affects cellular growth, differentiation and apoptosis in various embryonic and adult tissues [9,10]. All-trans RA (ATRA) has been reported being an agonist for multiple nuclear receptors, including RA receptors (RARs) [11,12], peroxisome proliferator-activated receptor $\delta$ (PPAR $\delta$, also designated PPAR $\beta$ ) [13], testicular orphan receptor 4 (TR4) [14] and chicken ovalbumin upstream promoter transcription factor II (COUP-TFII) [15]. It has been proposed that PPAR $\delta$ mediates part of the metabolic effects of ATRA [16]. Additionally, ATRA has been shown to regulate gene

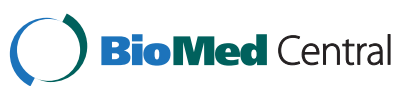


expression in a nongenomic manner [17]. However, it is believed that most effects of ATRA are mediated by RARs that upon heterodimerization with retinoid $\mathrm{X}$ receptors control gene expression through binding to RA response elements in regulatory regions of target genes [9,18].

High concentrations of ATRA inhibit differentiation of 3T3-L1 white preadipocytes and C3H10T $1 \frac{1}{2}$ mesenchymal stem cells [19-21], whereas low concentrations have been shown to stimulate white adipogenesis of Ob1771 cells [22]. The inhibition of adipogenesis by ATRA is mediated by RARs and is linked to suppression of CCAAT/enhancer-binding protein $\beta$ activity and induction of antiadipogenic genes [19,21,23].

The UCP1 gene of mice, rats and humans contains RAR-responsive elements in its enhancer region and ATRA has been shown to promote UCP1 expression and oxidative metabolism in cultured rodent adipocytes [24-31]. Moreover, treatment of mice with ATRA causes increased expression of UCP1 in WAT and BAT [17,28,31,32].

In the present study we compared the response of mouse and human preadipocytes and mature adipocytes to ATRA, with emphasis on the effects on differentiation and UCP1 expression. In addition, we have studied the importance of RARs, PPAR $\delta$ and PGC- $1 \alpha$ for the regulation of UCP1 expression by ATRA. We find that ATRA increases UCP1 expression in all mouse adipocyte models studied, including 3T3-L1 white adipocytes, and that this induction is mediated by RARs and is independent of PPAR $\delta$ and PGC- $1 \alpha$. Finally, ATRA does not increase UCP1 expression in any of the human adipocytes examined in this study.

\section{Results}

\section{Exposure of differentiating mouse adipocytes to ATRA} increases UCP1 expression

In order to examine the effects of ATRA on differentiating mouse adipocytes, we exposed four cell models of adipogenesis to a range of ATRA concentrations (10 nM to $10 \mu \mathrm{M})$ throughout the course of the differentiation process, i.e. between days -2 (the time of confluence) and 8 (designated chronic exposure). Gene expression was analyzed at day 8. We estimated the degree of differentiation by measuring mRNA levels of the adipocyte marker gene fatty acid-binding protein 4 (FABP4, also designated aP2). Expression of the brown fat-specific UCP1 gene was determined at both the mRNA and protein levels, and the expression of RAR $\beta$ was used to estimate the degree of activation of RARs, as the RAR $\beta$ gene is responsive to retinoids $[33,34]$. The cells used were 3 T3-L1 preadipocytes, wild-type (WT) mouse embryo fibroblasts (MEFs) and the mesenchymal stem cell line $\mathrm{C} 3 \mathrm{H} 10 \mathrm{~T}^{1} / 2$ as models of white adipocyte differentiation [35,36], and MEFs lacking a functional retinoblastoma gene ( $\mathrm{Rb}-/-)$ as a model of brown adipocyte differentiation [35].
RAR $\beta$ expression increased dose-dependently in response to treatment with ATRA in 3T3-L1, WT MEFs and C3H10T $1 \frac{1}{2}$ cells, whereas the same pattern was not observed in $\mathrm{Rb}-/-$ MEFs (Figure 1A-D). A dose-dependent reduction of FABP4 expression was seen in WT MEFs, $\mathrm{C} 3 \mathrm{H} 10 \mathrm{~T}^{1} / 2$ and $\mathrm{Rb}-/-$ MEFs, whereas only the highest level of ATRA $(10 \mu \mathrm{M})$ blocked adipose conversion of 3T3-L1 cells (Figure 1A-D). ATRA in intermediate concentrations $(1 \mu \mathrm{M}$ in 3T3-L1, $0.1 \mu \mathrm{M}$ and $1 \mu \mathrm{M}$ in WT MEF-derived adipocytes and $0.1 \mu \mathrm{M}$ in $\mathrm{C} 3 \mathrm{H} 10 \mathrm{~T}^{1} \frac{1}{2}$ and $\mathrm{Rb}-/$ - adipocytes) induced expression of UCP1 at both mRNA and protein levels, with a maximum fold induction of mRNA levels of $4,18,4$ and 3 in 3T3-L1, WT MEFderived, C3H10T $1 / 2$ and $\mathrm{Rb}-/-$ MEF-derived adipocytes, respectively (Figure 1A-E). Although ATRA in intermediate concentrations induced expression of UCP1 in all cases, the absolute level of UCP1 varied substantially between the cell models, being highest in Rb-/- adipocytes and lowest in WT MEF-derived adipocytes. In summary, chronic exposure to high concentrations of ATRA inhibits adipocyte differentiation, whereas intermediate concentrations cause increased expression of UCP1, even in 3T3-L1 white adipocytes.

\section{Exposing mature mouse adipocytes to ATRA enhances expression of UCP1}

In addition to the chronic exposure to ATRA described above, we also analyzed the effects of exposing mature mouse adipocytes to ATRA at day 8 (designated acute exposure). In this case, we used a fixed concentration of ATRA $(1 \mu \mathrm{M})$ and harvested RNA and protein after $24 \mathrm{~h}$ (i.e. at day 9). Expression of UCP1 and RAR $\beta$ increased in response to ATRA compared to vehicle in WT and $\mathrm{Rb}-/-$ MEF-derived and C3H10T $1 \frac{1}{2}$ adipocytes, but not in 3T3L1 adipocytes, with UCP1 mRNA levels increasing 15-, 4.6- and 2.5-fold, respectively, in the former three cell models (Figure 2A-D). Levels of UCP1 protein mirrored the levels of UCP1 mRNA (Figure 2E). FABP4 mRNA levels were slightly reduced by the acute exposure to ATRA in MEF-derived adipocytes, but not in 3T3-L1 and C3H10T $1 \frac{1}{2}$ adipocytes.

\section{RARs mediate the effects of ATRA}

As ATRA has been shown to bind and activate a range of nuclear receptors, we wished to identify the relevant targets of ATRA mediating the effects observed above. Therefore, we treated WT MEFs with TTNPB, a pan-RAR agonist not displaying agonist activity toward PPAR $\delta$ [13], using the two same experimental setups described above. Both chronic application of TTNPB (Figure 3A) and acute application of TTNPB to mature adipocytes (Figure $3 \mathrm{~B}$ ) resulted in expression patterns of FABP4, UCP1 and RAR $\beta$ similar to those observed upon treatment with ATRA (see Figures 1 and 2). Expression levels of UCP1 reached 


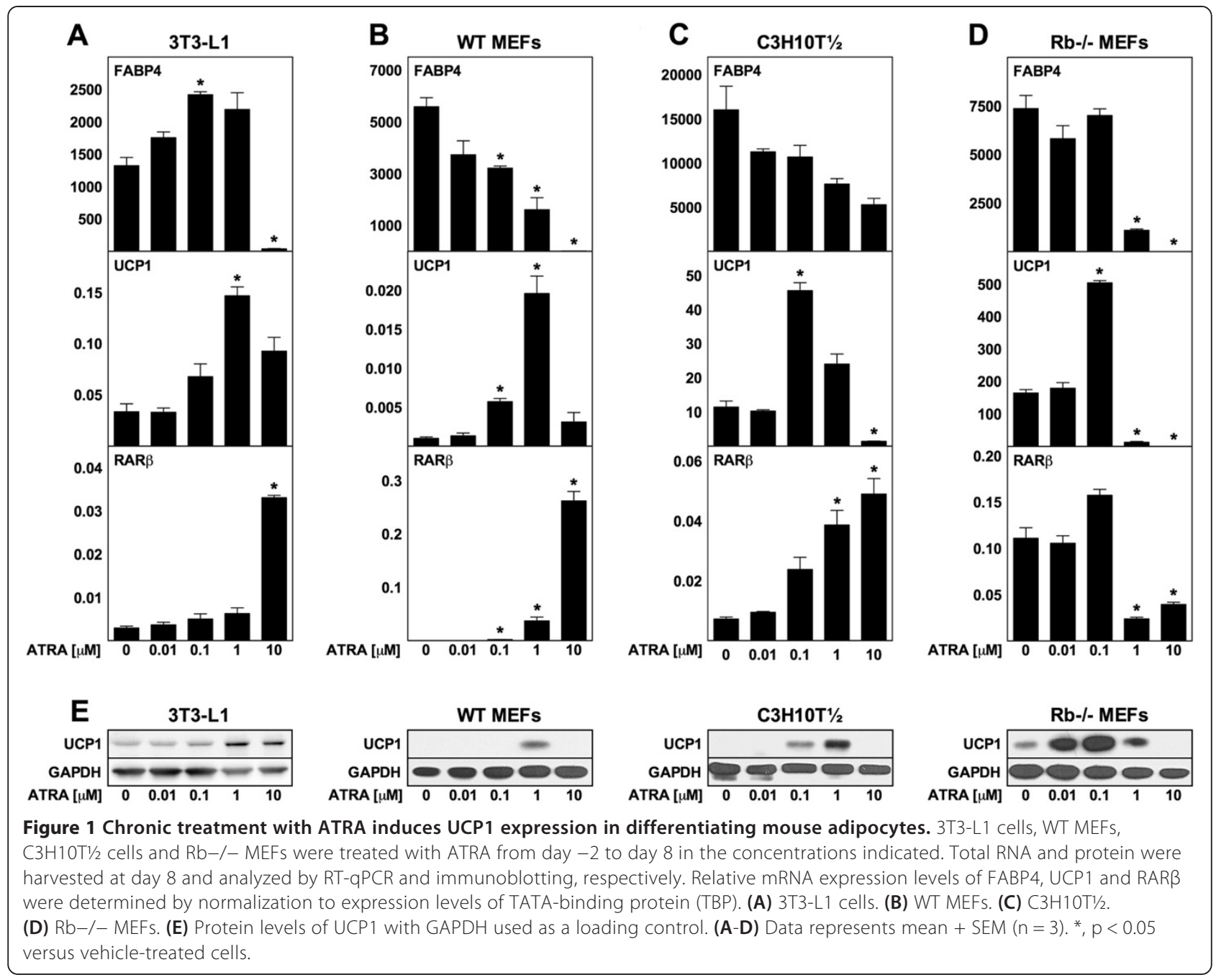

a peak induction of 25-fold in chronically treated adipocytes (1 nM TTNPB) (Figure 3A) and 6-fold after treatment of mature adipocytes with $1 \mathrm{nM}$ TTNPB for $24 \mathrm{~h}$ (Figure 3B). Next, we investigated if the pan-RAR antagonist BMS493 could inhibit the UCP1-inducing effects of ATRA. When applied chronically during differentiation (Figure 3C) and acutely to mature adipocytes (Figure 3D), BMS493 eliminated and blunted, respectively, the enhanced expression of UCP1 caused by ATRA. These results strongly suggest that the action of ATRA is mediated through RARs.

To delineate which of the three RAR isoforms that are responsible for the upregulation of UCP1, we used three RAR subtype-selective agonists: AM580 (RAR $\alpha$ selective); tazarotene (RAR $\beta / \gamma$ selective) and CD1530 (RAR $\gamma$ selective). All three agonists caused an induction of UCP1 expression when administered chronically to differentiating WT MEFs (Figure 4A). AM580 and tazarotene induced the highest fold increase in UCP1 expression (11- and 8-fold, respectively). A dose-dependent increase in RAR $\beta$ mRNA and a reduction of FABP4 mRNA levels were observed for all three agonists (Figure 4A). Notably, as AM580 has a 30-40-fold selectivity for RAR $\alpha$ compared to RAR $\beta$ and RAR $\gamma$ [37], the observation that $10 \mathrm{nM}$ AM580 was sufficient to increase UCP1 levels suggests that activation of RAR $\alpha$ is sufficient (Figure 4A). However, tazarotene and CD1530 were also able to increase UCP1 levels despite a low affinity for RAR $\alpha$, indicating that activation of any RAR subtype is capable of increasing UCP1 expression in mouse adipocytes.

When the three agonists were acutely supplemented to mature WT MEF-derived adipocytes, UCP1 mRNA levels were significantly induced after $24 \mathrm{~h}$, with AM580 and tazarotene displaying the most potent effect (Figure 4B).

\section{PPAR $\delta$ activation does not increase UCP1 expression in MEF-derived white adipocytes}

As mentioned, ATRA can bind to PPAR $\delta$ and increase its transcriptional activity [13,38], and activation of PPAR $\delta$ is believed to regulate thermogenic gene expression in adipose tissue $[39,40]$. To determine if activation of PPAR $\delta$ 


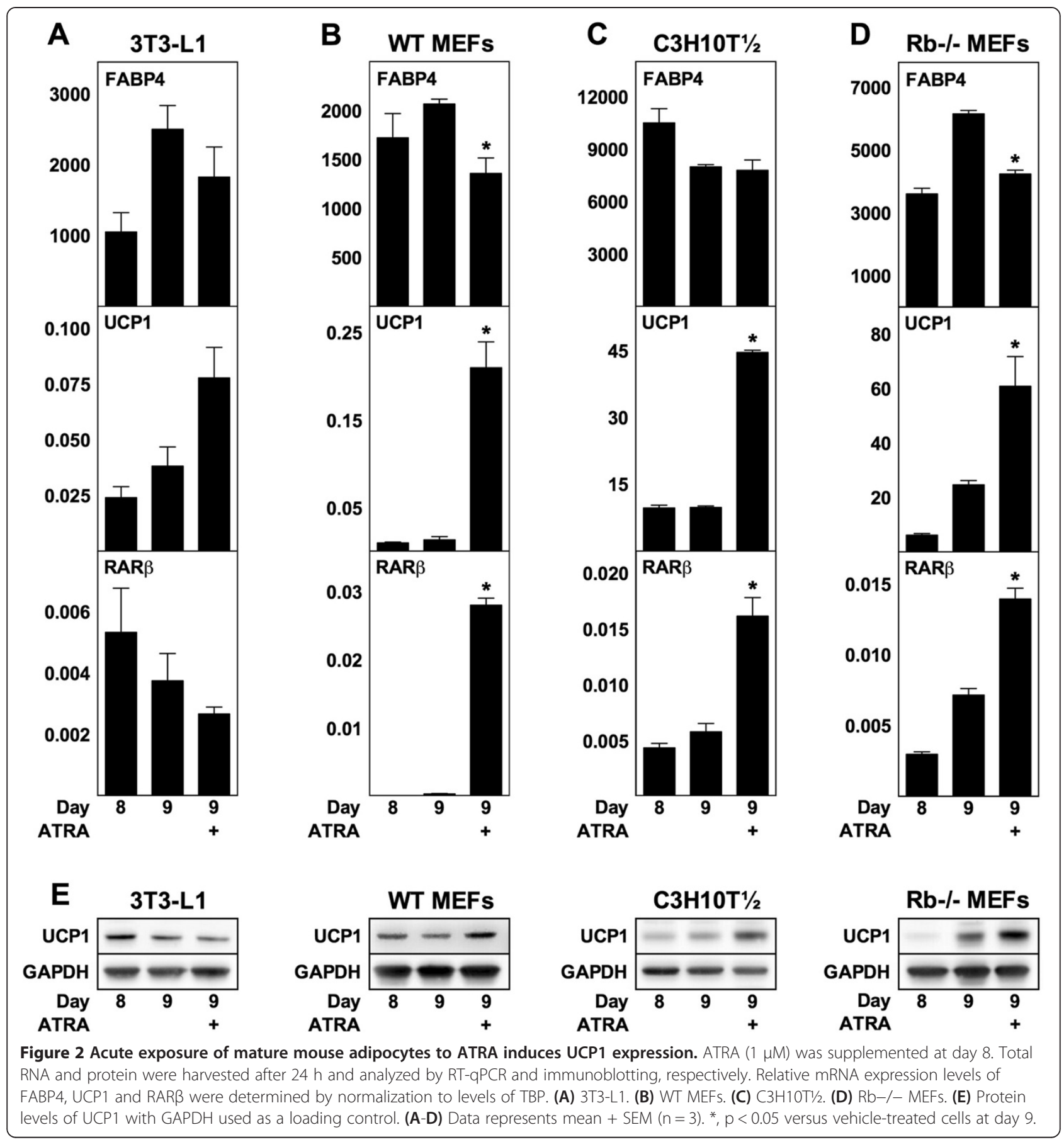

mimics the effects observed with ATRA, we exposed WT MEFs to the PPAR $\delta$ agonist GW501516 either during differentiation (Figure 5A) or acutely to mature adipocytes (Figure 5B). GW501516 did not change either UCP1 or FABP4 mRNA levels in either case (Figure 5A and B). The PPAR $\delta$ target gene adipose differentiation-related protein (ADRP, also designated adipophilin and perilipin 2) [41] was significantly upregulated when GW501516 was added chronically (Figure 5A).
The effects of ATRA on UCP1 expression is not dependent on PGC-1a

PGC- $1 \alpha$ is a metabolically regulated transcriptional coactivator that is known to induce UCP1 levels in adipocytes and to interact with RAR $\alpha$ in an ATRA-dependent manner [42]. To investigate whether PGC-1 $\alpha$ is required for the ATRA-mediated effects, we compared immortalized brown preadipocyte cell lines from WT and PGC-1 $\alpha$-deficient mice [43]. ATRA was supplemented either chronically 

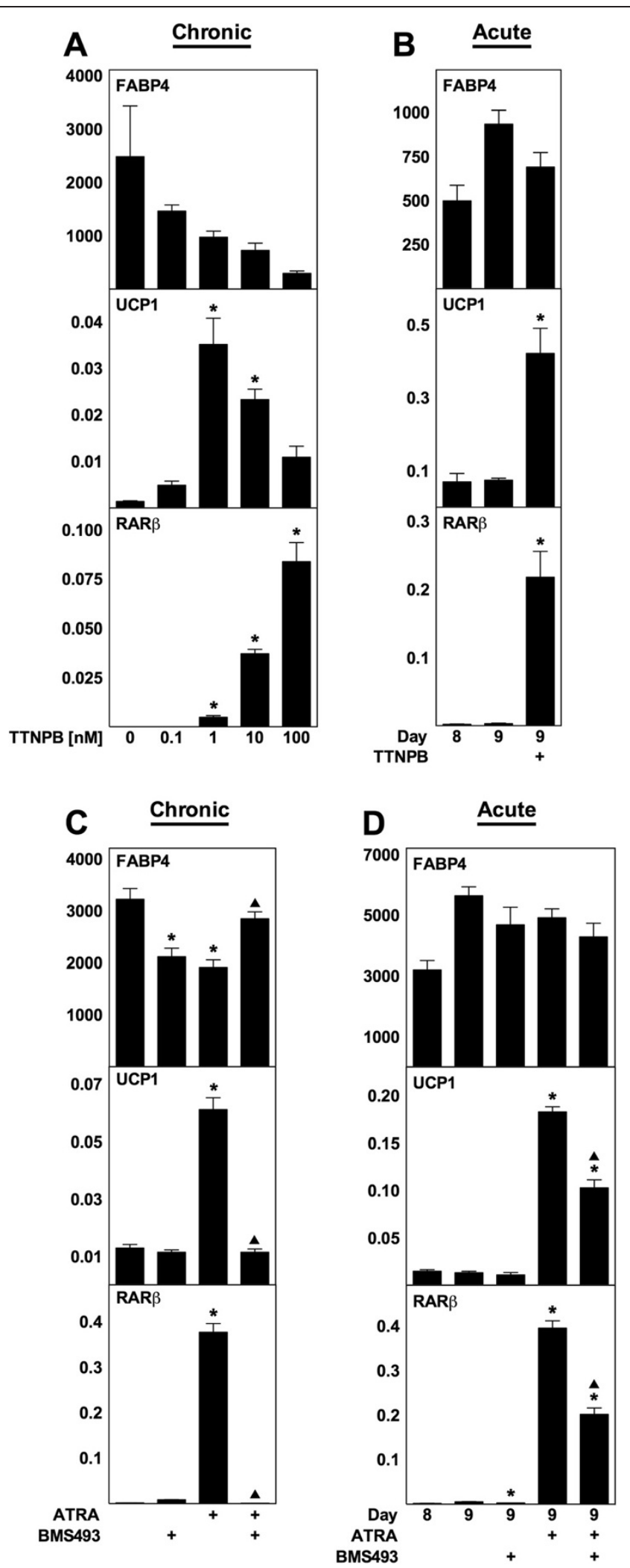

Figure 3 (See legend on next page.) 
(See figure on previous page.)

Figure 3 TTNPB mimics and BMS493 inhibits the effects of ATRA in WT MEFs. Total RNA was harvested at the indicated days (day 8 in panels $A$ and C) and analyzed by RT-qPCR. Relative mRNA expression levels of FABP4, UCP1 and RARß were determined by normalization to TBP. (A) TTNPB was supplemented to differentiating cells from day -2 to day 8 at the concentrations indicated. (B) TTNPB (1 nM) was acutely

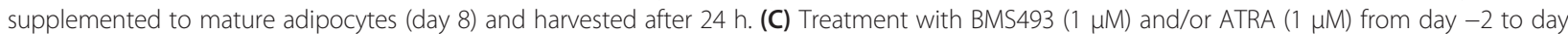
8. (D) Acute supplementation of BMS493 $(1 \mu \mathrm{M})$ and/or ATRA $(1 \mu \mathrm{M})$ to mature adipocytes from day 8 and harvested after $24 \mathrm{~h}$. Data represents mean + SEM $(n=3) .{ }^{*}, p<0.05$ versus vehicle-treated cells. ${ }^{\mathbf{\Delta}}, p<0.05$ versus ATRA-treated cells.

during differentiation or acutely to mature adipocytes. UCP1 expression was increased at intermediate concentrations of ATRA in the chronically treated PGC- $1 \alpha+/+$ and PGC-1 $\alpha-/$ - adipocytes (Figure 6A). The highest level of UCP1 was observed with $0.1 \mu \mathrm{M}$ ATRA in WT adipocytes (3.5-fold above vehicle), but with $1 \mu \mathrm{M}$ ATRA in PGC-1 $\alpha-/$ - adipocytes (17-fold above vehicle). Of notice, basal expression of UCP1 was lower in PGC-1 $\alpha$-deficient fat cells (Figure 6A and B). A minor decrease in FABP4 expression with $10 \mu \mathrm{M}$ ATRA and a dose-dependent increase in RAR $\beta$ expression were observed (Figure 6A).

Exposing mature PGC- $1 \alpha+/+$ and PGC- $1 \alpha-/$ - adipocytes to $1 \mu \mathrm{M}$ ATRA elicited significant induction of UCP1 after $24 \mathrm{~h}$ (Figure 6B). Thus, enhanced expression of UCP1 caused by ATRA does not require PGC-1 $\alpha$.

\section{ATRA inhibits human adipocyte differentiation in a} dose-dependent manner and does not increase UCP1 expression

To investigate if chronic treatment with ATRA had the same effects on human adipocytes as observed with mouse adipocytes, we exposed the human white preadipocyte cell line SGBS [44], human multipotent adipose-derived stem cells (hMADS) $[45,46]$ and primary human white preadipocytes to various concentrations of ATRA during differentiation (Figure 7A-C). The human adipocytes were
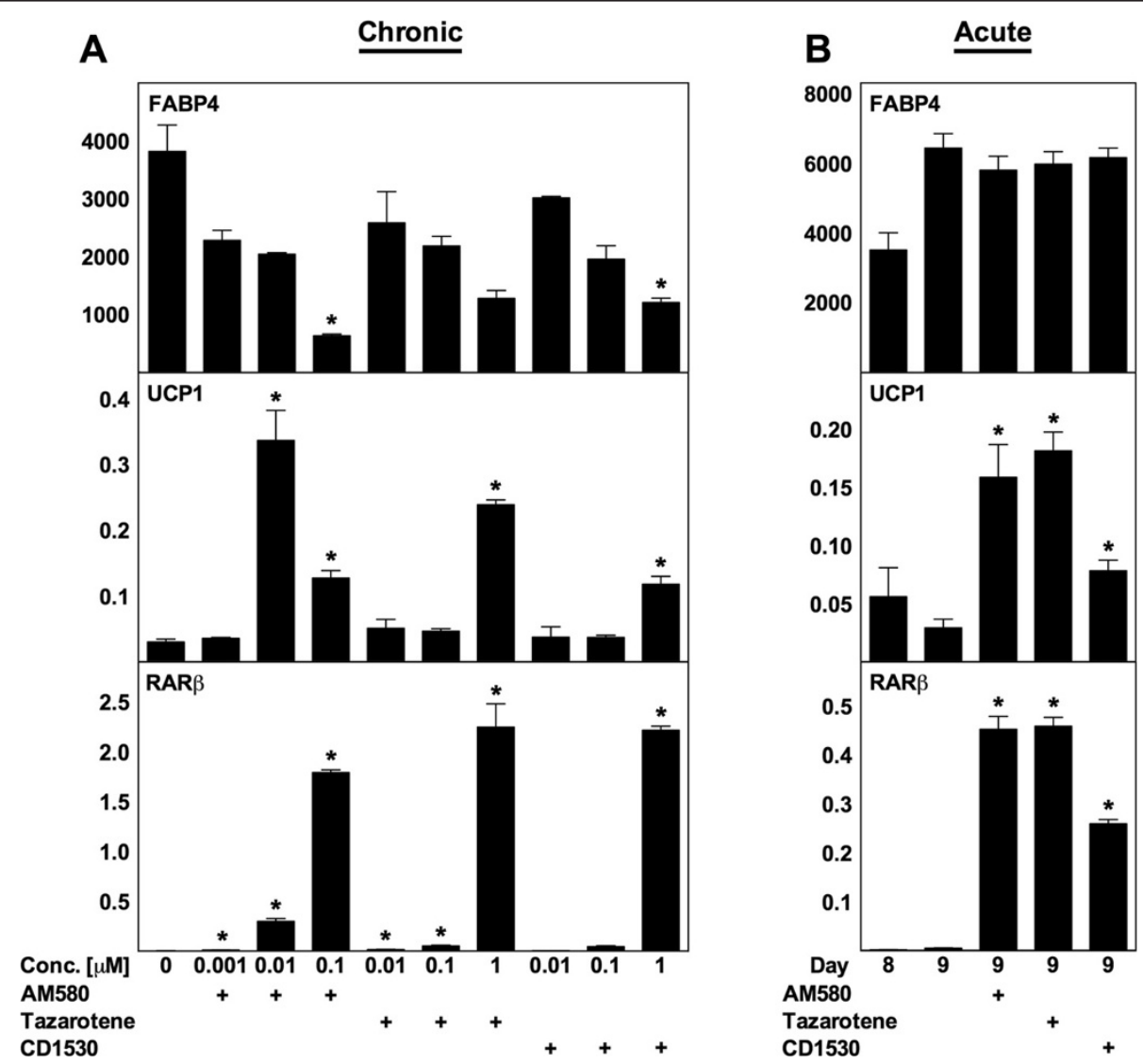

Figure 4 RAR subtype-selective ligands induce UCP1 expression in WT MEFs. Total RNA was harvested at day 8 (panel A) or at the indicated days (panel B) and analyzed by RT-qPCR. Relative mRNA expression levels of FABP4, UCP1 and RAR $\beta$ were determined by normalization to TBP. (A) RAR subtype-selective ligands AM580, tazarotene and CD1530 were supplemented from day -2 to day 8 at the concentrations indicated. (B) RAR subtype-selective ligands AM580 (1 $\mu \mathrm{M})$, tazarotene $(1 \mu \mathrm{M})$ and CD1530 (1 $\mu \mathrm{M})$ were acutely supplemented to mature adipocytes from day 8 and harvested after 24 h. Data represents mean + SEM $(n=3) .{ }^{*}, p<0.05$ versus vehicle-treated cells. 


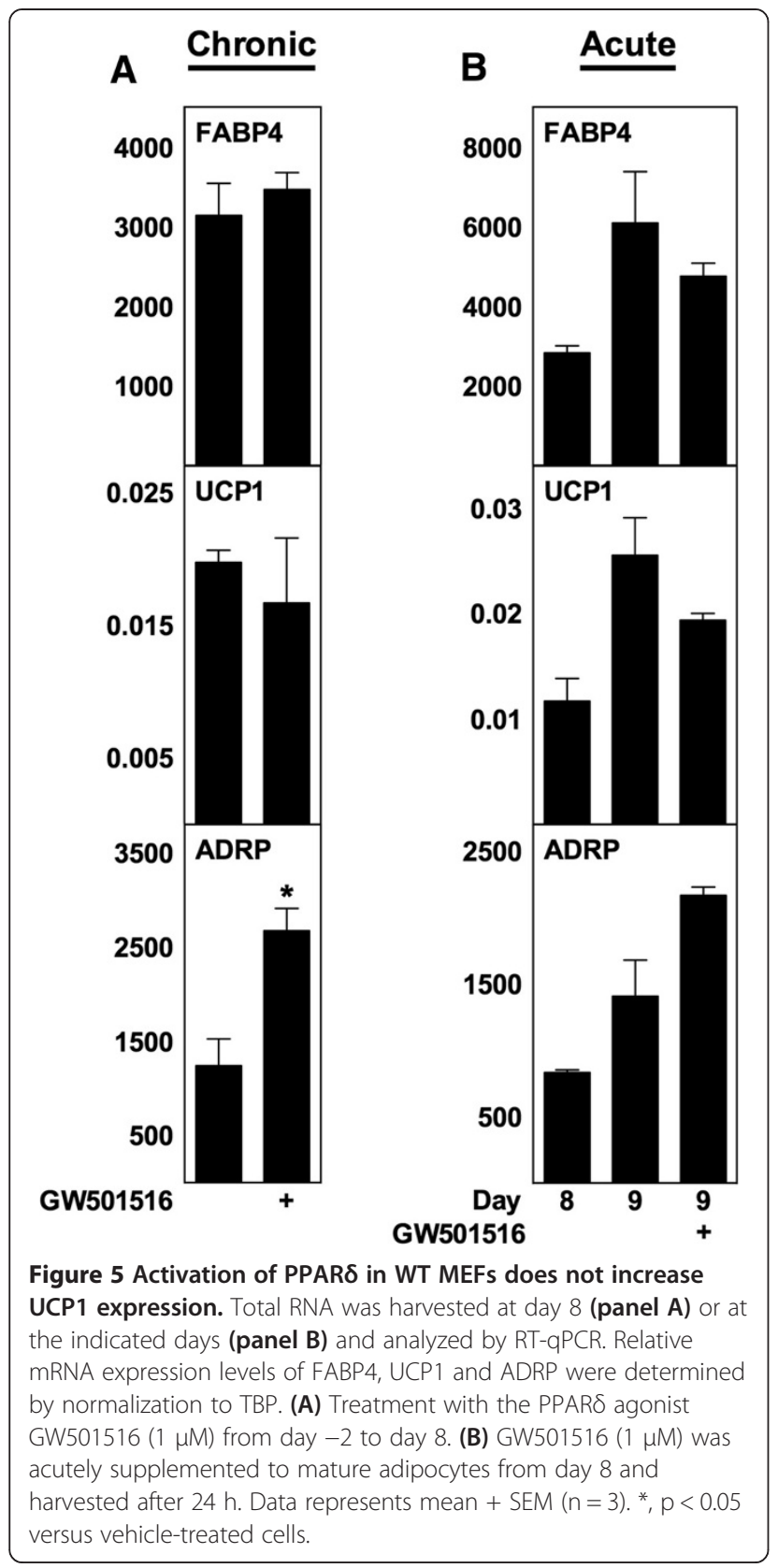

considered mature on day 12 , and not on day 8 as the mouse adipocytes, as their morphological differentiation into adipocytes was substantially slower. High concentrations of ATRA inhibited differentiation of SGBS $(10 \mu \mathrm{M})$, hMADS $(10 \mu \mathrm{M})$ and primary preadipocytes $(1$ and $10 \mu \mathrm{M})$, as estimated by expression of FABP4 mRNA. RAR $\beta$ expression increased dose-dependently in all three cell models (Figure 7A-C). Interestingly, the low basal UCP1 mRNA levels in SGBS and hMADS adipocytes did not increase at any concentration of ATRA compared with vehicle-treated cells and were lower with 1 and $10 \mu \mathrm{M}$ ATRA (Figure 7A and B). Notably, FABP4 expression was not affected by $1 \mu \mathrm{M}$ ATRA. Basal expression of UCP1 in primary preadipocytes exposed to ATRA during differentiation was strongly inhibited by ATRA, an inhibition observed even at the lowest concentration used (10 nM) (Figure 7C). Levels of UCP1 protein were determined in SGBS and hMADS adipocytes and confirmed that ATRA did not increase UCP1 levels (Figure 7D). Acute exposure of mature adipocytes to $1 \mu \mathrm{M}$ ATRA did not result in any significant changes in mRNA levels of FABP4 or mRNA and protein levels of UCP1 compared to vehicle treatment in SGBS, hMADS or primary cells (Figure 8). Basal UCP1 mRNA expression was undetectable in primary human white adipocytes from another donor and expression remained undetectable after treatment with ATRA (data not shown). In summary, ATRA does not increase expression of UCP1 in the human adipocyte models studied here.

\section{Discussion}

In this study, we report the effects of ATRA on differentiation and UCP1 expression in various mouse and human adipocytes. We find that high concentrations of ATRA inhibit mouse and human adipogenesis, whereas lower concentrations enhance UCP1 expression in mouse, but not in human, adipocytes. In addition, we show that the effects of ATRA are mediated by RARs and not by PPAR $\delta$ or other ATRA-activated nuclear receptors. Moreover, the enhanced expression of UCP1 in response to ATRA is independent of PGC- $1 \alpha$.

Adipocyte and adipose tissue function are impacted by ATRA $[47,48]$. Expression of UCP1 is reduced in BAT of mice fed vitamin A-depleted feed $[17,49]$ and exogenous ATRA enhances expression of UCP1 in both WAT and BAT of mice and rats $[16,17,28,32,49,50]$. Expression of UCP1 is induced by ATRA in primary brown adipocytes from mice and rats as well as in mouse brown adipocyte cell lines [24,26,28,29,51-53]. Moreover, UCP1 expression is strongly induced in MEF-derived white adipocytes [31]. Contrary, ATRA has been reported not to induce expression of UCP1 in mature 3T3-L1 adipocytes and mouse primary white adipocytes $[16,30,54]$. Exposure to ATRA leads to activation of $\mathrm{p} 38$ mitogen-activated protein kinase (MAPK), an activation that is required for full induction of UCP1 expression by ATRA [29,31].

ATRA has been reported to activate three nuclear receptors besides RARs, namely PPAR $\delta$, COUP-TFII and TR4. The induction of UCP1 observed in the mouse cells applied in this study is unlikely to be mediated by COUPTFII and TR4, as the app. $\mathrm{EC}_{50}$ of ATRA are $20 \mu \mathrm{M}$ [15] and $24 \mu \mathrm{M}$ [14], respectively, which is 20 to 240 times higher than the concentrations inducing UCP1. Although the $\mathrm{EC}_{50}$ of ATRA for PPAR $\delta$ is much lower than for COUP-TFII and TR4 (app. $200 \mathrm{nM}$ ) [13], PPAR $\delta$ is not mediating the effects of ATRA either. Firstly, the RAR agonist TTNPB mimics the effects of ATRA (see Figure 3), 


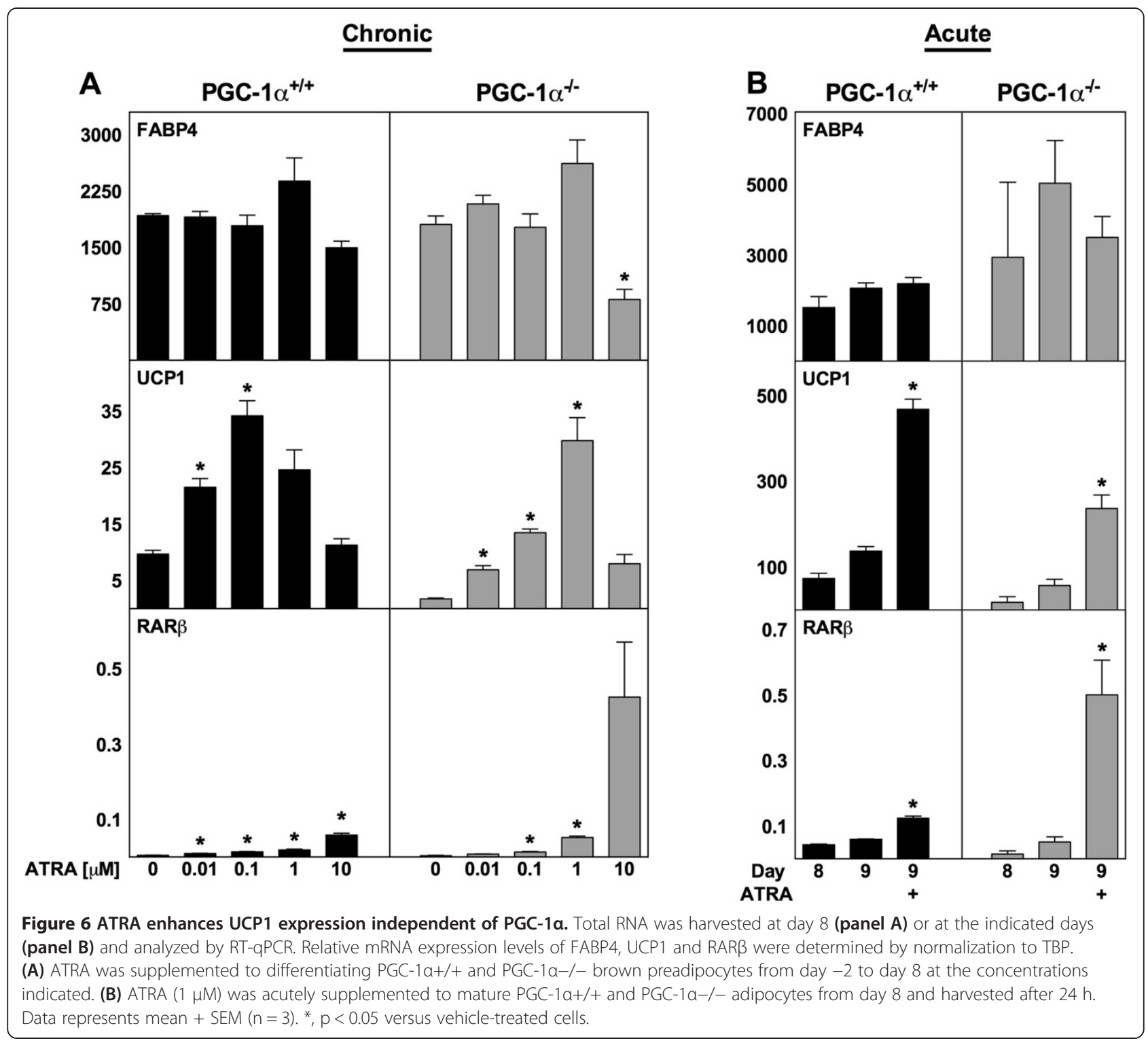

but does not bind to PPAR $\delta$ [13]. Secondly, a potent PPAR $\delta$ agonist does not enhance expression of UCP1 (see Figure 5). Thirdly, a RAR antagonist attenuates the effects of ATRA (see Figure 3). In this study, we have not addressed the potential involvement of nongenomic effects of ATRA, e.g. activation of p38 MAPK and the cell surface receptor responsible for retinol uptake called stimulated by retinoic acid gene 6 [55].

At intermediate concentrations of ATRA, we consistently observe an induction of UCP1 expression in mouse adipocytes. This does not only occur in the mouse cells shown here, but was also observed with WT-1 brown adipocytes [56,57] and 3T3-F442A white adipocytes (data not shown). Thus, our results demonstrate that ATRA can cause an induction of UCP1 expression in white adipocyte cell models of mouse origin. It is tempting to speculate that exposure to ATRA will cause white preadipocytes and mature adipocytes to transdifferentiate into brown-like adipocytes in vitro. However, in order to confirm if a transdifferentiation event has taken place in our study, a more detailed gene expression analysis is required combined with a characterization of mitochondrial function.

Using three cell models of human origin, SGBS and hMADS cells as well as primary subcutaneous adipocytes from two different donors, we failed to detect an induction of UCP1 expression by ATRA (see Figures 7 and 8). hMADS cells have been proposed to represent brown or brown-like adipocytes, the latter due to the induction of UCP1 expression in response to prolonged culture in the presence of rosiglitazone [58,59] or upon treatment with atrial natriuretic peptide [60]. Despite being considered white fat cells, SGBS and primary subcutaneous human 


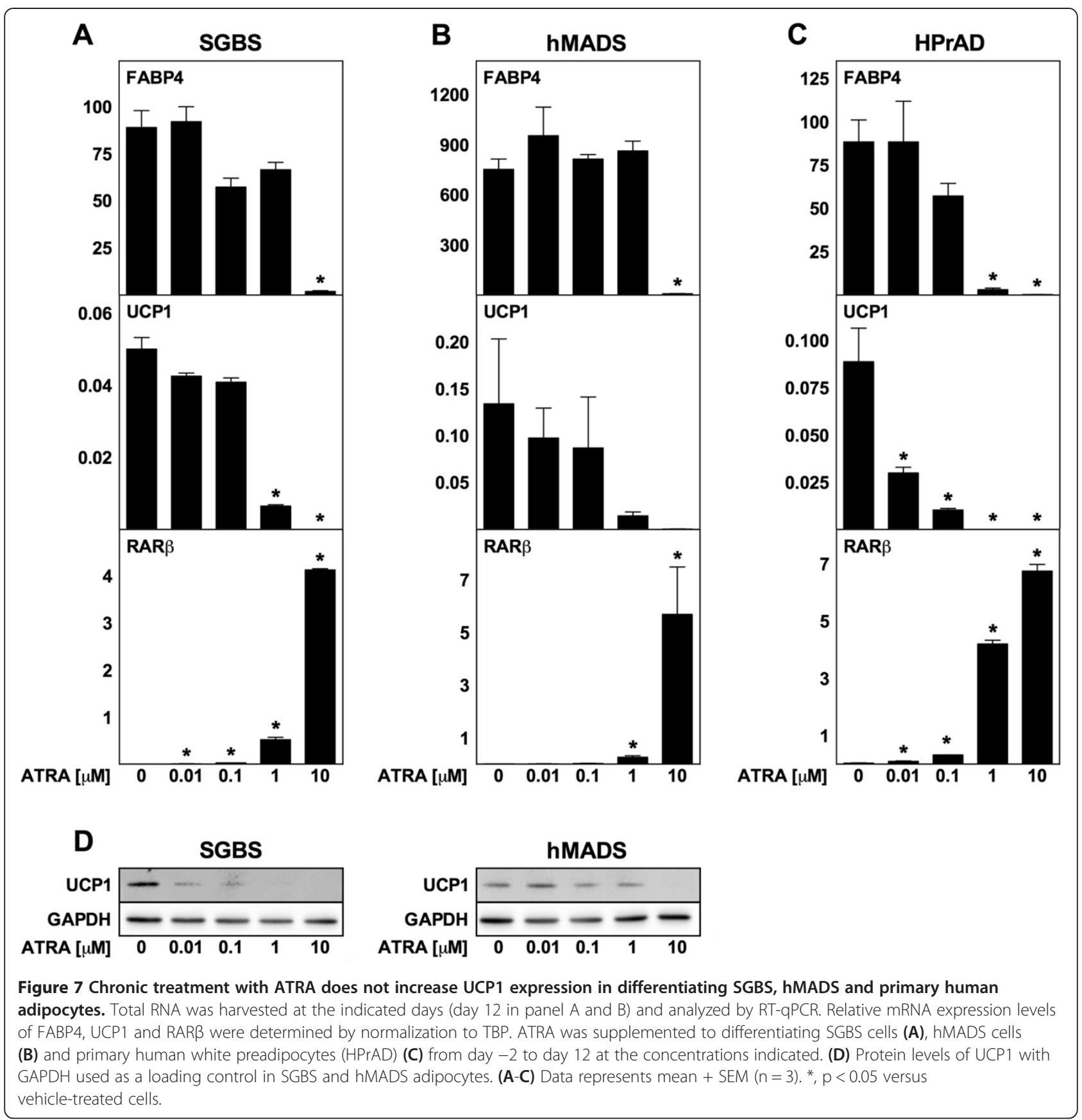

adipocytes have the ability to induce expression of UCP1 in response to genetic manipulation $[61,62]$. Thus, the lack of effect of ATRA in the human adipocyte models studied here cannot be explained by an inherent inability to induce expression of UCP1. Consistently, to our knowledge, an induction of the endogenous human UCP1 gene by ATRA has never been reported. Nevertheless, we cannot rule out that the lack of response in our study is due to the experimental setup or the human cell models used. In particular, it remains to be shown if primary human brown adipocytes respond to ATRA by increasing UCP1 expression. However, as we consistently observe enhanced expression of UCP1 by intermediate concentrations of ATRA in mouse fat cells, we find this difference between mouse and human adipocytes noteworthy.

\section{Conclusions}

In conclusion, we demonstrate that ATRA is a powerful inducer of UCP1 expression in mouse white and brown adipocytes, supporting that ATRA has the capacity to increase the potential for uncoupled respiration in those cells. The increased expression of UCP1 in response to 


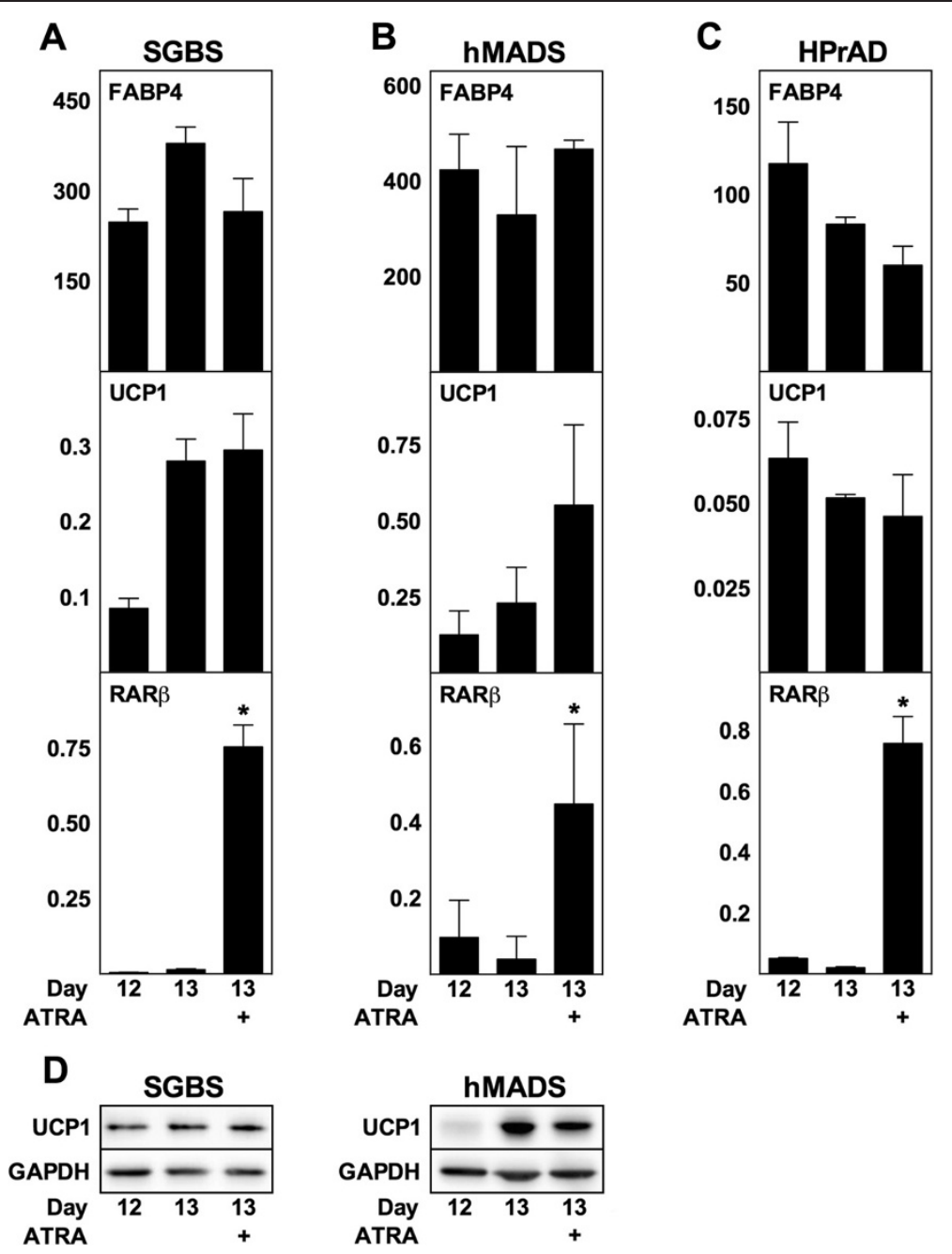

Figure 8 Acute exposure of mature human adipocytes to ATRA does not induce UCP1 expression. ATRA (1 $\mu$ M) was supplemented to mature SGBS adipocytes (A), hMADS adipocytes (B) and primary human white preadipocytes (HPrAD) (C) from day 12 and harvested after $24 \mathrm{~h}$. (D) Protein levels of UCP1 with GAPDH used as a loading control in SGBS and hMADS adipocytes. (A-C) Data represents mean + SEM $(n=3) .{ }^{*}$, $p<0.05$ versus vehicle-treated cells.

ATRA is mediated by RARs, not PPAR $\delta$, and is independent of PGC-1 $\alpha$. We do not find induction of UCP1 gene expression by ATRA in the human adipocytes studied here, but whether this applies to the human UCP1 gene in general remains to be determined. Nevertheless, differences between rodents and humans in terms of regulation of UCP1 expression are highly relevant, as modulation of BAT activity and browning of WAT are being considered as potential anti-obesity targets. More studies comparing rodent and human adipocytes are needed to understand their similarities and differences with respect to regulation of UCP1 expression.

\section{Methods}

\section{Cell culture}

WT and $\mathrm{Rb}-/-$ MEFs were propagated and differentiated as previously described [56]. Immortalized PGC- $1 \alpha+/+$ and
PGC-1 $\alpha-/-$ brown preadipocyte cell lines were obtained from Dr. Bruce M. Spiegelman [43], and C3H10T $1 \frac{1}{2}$ mesenchymal stem cells [36] and 3T3-L1 white preadipocytes [63] were obtained from Dr. Karsten Kristiansen. Brown preadipocyte cell lines and $\mathrm{C} 3 \mathrm{H}_{10 \mathrm{~T}} 1 / 2$ cells were propagated in Dulbecco's Modified Eagle's Medium (DMEM) (Life Technologies) supplemented with 10\% foetal bovine serum (FBS) (Life Technologies) and differentiated as WT and Rb-/- MEFs. 3T3-L1 cells were propagated in DMEM supplemented with $10 \%$ bovine serum and differentiated as WT and Rb-/- MEFs. Thus, all mouse cells were cultured in the presence of rosiglitazone from day 0 until the time of harvesting. The SGBS white preadipocyte cell line was obtained from Dr. Martin Wabitch [44] and propagated in Advanced DMEM/F12 (Life Technologies) with 10\% FBS and $2 \mathrm{mM} \mathrm{L-glutamine} \mathrm{(Life} \mathrm{Technologies).}$ Two days postconfluent cells (designated day 0) were 
induced to differentiate in Advanced DMEM/F12 with 2\% FBS supplemented with $0.86 \mu \mathrm{M}$ insulin (Roche), $1 \mu \mathrm{M}$ dexamethasone (Sigma-Aldrich), $0.5 \mathrm{mM}$ 3-isobutyl-1methylxanthine (IBMX) (Sigma-Aldrich), $1 \mu \mathrm{M}$ rosiglitazone (Cayman Chemical), $1 \mu \mathrm{M}$ cortisol (Sigma-Aldrich) and $1 \mathrm{nM}$ 3,3',5-triiodo-L-thyronine ( $\mathrm{T}_{3}$ ) (Sigma-Aldrich). On day 3 the cells were fed the same medium as on day 0 . On days 6, 9 and 12 medium contained 2\% FBS, $0.86 \mu \mathrm{M}$ insulin, $1 \mu \mathrm{M}$ rosiglitazone and $1 \mathrm{nM} \mathrm{T}$. hMADS cells were obtained by Dr. Christian Dani and their propagation and differentiation were carried out as described $[45,46]$ with minor modifications. Briefly, hMADS cells were cultured in low glucose DMEM (Lonza) supplemented with 10\% FBS, 2 mM L-glutamine, 10 mM HEPES (Lonza) and $2.5 \mathrm{ng} / \mathrm{ml}$ human fibroblast growth factor 2 (Life Technologies). Two days postconfluent cells (designated day 0) were induced to differentiate in low glucose DMEM/Ham's F12 medium (Lonza) with 10 mM HEPES, $2 \mathrm{mM}$ L-glutamine supplemented with $10 \mu \mathrm{g} / \mathrm{ml}$ transferrin, $0.86 \mu \mathrm{M}$ insulin, $0.1 \mu \mathrm{M}$ rosiglitazone, $0.2 \mathrm{nM} \mathrm{T}_{3}$, $1 \mu \mathrm{M}$ dexamethasone and 0.5 mM IBMX. At days 2, 4, 6 , 8,10 and 12 medium was supplemented with $10 \mathrm{mM}$ HEPES, $2 \mathrm{mM}$ L-glutamine, $10 \mu \mathrm{g} / \mathrm{ml}$ transferrin, $0.86 \mu \mathrm{M}$ insulin, $0.1 \mu \mathrm{M}$ rosiglitazone and $0.2 \mathrm{nM} \mathrm{T}_{3}$. Primary human white subcutaneous preadipocytes (Lonza) were cultured in PBM-2 medium (Lonza). Two days postconfluent preadipocytes (designated day 0 ) were induced to differentiate with PBM-2 medium supplemented with insulin, dexamethasone, IBMX and indomethacin (all supplied by Lonza) according to the instructions of the manufacturer. On day 3 the cells were refed the same medium as on day 0 . On days 6, 9 and 12 cells were refreshed with PBM-2 medium containing insulin and indomethacin. All media described above were supplemented with $50 \mathrm{U} / \mathrm{ml}$ penicillin and $50 \mu \mathrm{g} / \mathrm{ml}$ streptomycin, and all cells were cultured at $37^{\circ} \mathrm{C}$ in humidified atmospheric air with $5 \% \mathrm{CO}_{2}$, except for hMADS cells that were cultured with $10 \% \mathrm{CO}_{2}$.

Additional ligands were used in concentrations stated in figures and figure legends and were added from either day -2 and onwards in chronic treatment experiments or from day 8 (mouse cells) or day 12 (human cells) in experiments with acute exposure of mature adipocytes. ATRA, TTNPB and AM580 were purchased from Sigma-Aldrich. Tazarotene, CD1530 and BMS493 were purchased from Tocris Bioscience, and GW501516 was kindly provided by Novo Nordisk A/S. All nuclear receptor ligands were dissolved in dimethyl sulfoxide (DMSO) (Sigma-Aldrich), and dishes not supplemented with ligands were treated with an equal volume of DMSO.

\section{Reverse transcription-quantitative polymerase chain reaction} Total RNA was purified using TRI Reagent (Sigma-Aldrich). Reverse transcription (RT) and RT-quantitative polymerase chain reaction (RT-qPCR) were performed as previously described [56]. Primers used were: ADRP (mouse), fw-G AATTTCTGGTTGGCACTGT, rev-GACCATTTCTCAG CTCCACTC (80 bp); FABP4 (mouse), fw-TGGAAGCTT GTCTCCAGTGA, rev-AATCCCCATTTACGCTGATG (111 bp); RAR $\beta$ (mouse), fw-ACAGATCTCCGCAGCAT CAG, rev-GCATTGATCCAGGAATTTCCA (76 bp); TBP (mouse), fw-ACCCTTCACCAATGACTCCTATG, rev-AT GATGACTGCAGCAAATCGC (190 bp); UCP1 (mouse), fw-GGCATTCAGAGGCAAATCAGCT, rev-CAATGAA CACTGCCACACCTC (151 bp); FABP4 (human), fw-A GCACCATAACCTTAGATGGGG, rev-CGTGGAAGTG ACGCCTTTCA (132 bp); RAR $\beta$ (human), fw-AAGTGC TTTGAAGTGGGAATG，rev-GCTTTTCGGATCTTCT CTGTG (143 bp); TBP (human), fw-CCCGAAACGCCG AATATAA, rev-GAAAATCAGTGCCGTGGTTC (83 bp); UCP1 (human), fw-CCAACTGTGCAATGAAAGTGT, revCAAGTCGCAAGAAGGAAGGTA (81 bp).

\section{Whole cell extracts and immunoblotting}

Preparation of whole-cell extracts and immunoblotting were done as described [64]. Antibodies used were against glyceraldehyde 3-phosphate dehydrogenase (GAPDH) (Ab8245, Abcam) and UCP1 (Ab10983, Abcam).

\section{Statistical analysis}

All experiments were repeated at least three times and three dishes were harvested at each time point or treatment for each independent experiment. Data from a representative experiment are presented as mean of the three dishes (+SEM). Statistical significance was determined by Student's $t$-test. Bonferroni correction was applied when multiple comparisons were carried out.

\section{Abbreviations}

ADRP: Adipose differentiation-related protein; ATRA: All-trans RA; BAT: Brown adipose tissue; COUP-TFIl: Chicken ovalbumin upstream promoter transcription factor II; DMEM: Dulbecco's Modified Eagle's Medium; FABP4: Fatty acid-binding protein 4; FBS: Foetal bovine serum; GAPDH: Glyceraldehyde 3-phosphate dehydrogenase; HPrAD: Primary human white preadipocytes/adipocytes; IBMX: 3-isobutyl-1-methylxanthine; MAPK: Mitogen activated protein kinase; MEF: Mouse embryo fibroblast PGC-1a: PPARy coactivator-1a; PPAR: Peroxisome proliferator-activated receptor; RA: Retinoic acid; RAR: RA receptor; Rb: Retinoblastoma gene; RT-qPCR: Reverse transcription-quantitative polymerase chain reaction; $T_{3}$ : 3,3',5-triiodo-L-thyronine; TBP: TATA-binding protein; TR4: Testicular orphan receptor 4; UCP1: Uncoupling protein 1; WAT: White adipose tissue; WT: Wild-type.

\section{Competing interest}

The authors declare that they have no competing interests.

\section{Authors' contributions}

MM, MSI, BQ and JBH conceived and designed the experiments. MM, MSI, ALB, SW, CS, JSP, MMN and ASH performed the experiments. All authors analyzed and interpreted the data. MSI prepared the figures. MM, MSI and $\mathrm{JBH}$ wrote the paper. All authors read and approved the final manuscript.

\section{Acknowledgements}

We appreciate the generous gift of reagents from Drs. Bruce M. Spiegelman (Harvard Medical School, Dana Farber Cancer Institute, Boston, USA), Martin Wabitch (University of Ulm, Germany), Christian Dani (University of Nice 
Sophia Antipolis, France), Karsten Kristiansen (University of Copenhagen, Denmark) and Novo Nordisk A/S (Måløv, Denmark). Sally Winther is the recipient of a Novo Scholarship. This work was supported by grants to Jacob B. Hansen from the EU FP7 project DIABAT (HEALTH-F2-2011-278373), The Danish Medical Research Council, The Novo Nordisk Foundation, The Carlsberg Foundation, The Aase and Ejnar Danielsen Foundation, The Augustinus Foundation, The Hartmann Brothers' Foundation, The Beckett Foundation and Fonden til Laegevidenskabens Fremme.

\section{Author details}

'Department of Biology, University of Copenhagen, Universitetsparken 13, DK-2100 Copenhagen $\varnothing$, Denmark. ${ }^{2}$ Department of Biomedical Sciences, University of Copenhagen, Blegdamsvej 3, DK-2200 Copenhagen N, Denmark.

Received: 1 May 2013 Accepted: 18 September 2013

Published: 23 September 2013

\section{References}

1. Cannon B, Nedergaard J: Brown adipose tissue: function and physiological significance. Physiol Rev 2004, 84(1):277-359.

2. Nedergaard J, Bengtsson T, Cannon B: Unexpected evidence for active brown adipose tissue in adult humans. Am J Physiol Endocrinol Metab 2007, 293(2):E444-E452.

3. Cousin B, Cinti S, Morroni M, Raimbault S, Ricquier D, Penicaud L, Casteilla L: Occurrence of brown adipocytes in rat white adipose tissue: molecular and morphological characterization. J Cell Sci 1992, 103(Pt 4):931-942.

4. Himms-Hagen J, Cui J, Danforth E Jr, Taatjes DJ, Lang SS, Waters BL, Claus $\mathrm{TH}$ : Effect of CL-316,243, a thermogenic beta 3-agonist, on energy balance and brown and white adipose tissues in rats. Am J Physiol 1994 266(4 Pt 2):R1371-R1382.

5. Nedergaard J, Bengtsson T, Cannon B: Three years with adult human brown adipose tissue. Ann NY Acad Sci 2010, 1212:E20-E36.

6. Oberkofler H, Dallinger G, Liu YM, Hell E, Krempler F, Patsch W: Uncoupling protein gene: quantification of expression levels in adipose tissues of obese and non-obese humans. J Lipid Res 1997, 38(10):2125-2133.

7. Yang X, Enerback S, Smith U: Reduced expression of FOXC2 and brown adipogenic genes in human subjects with insulin resistance. Obes Res 2003, 11(10):1182-1191.

8. Semple RK, Crowley VC, Sewter CP, Laudes M, Christodoulides C, Considine RV, Vidal-Puig A, O'Rahilly S: Expression of the thermogenic nuclear hormone receptor coactivator PGC-1alpha is reduced in the adipose tissue of morbidly obese subjects. Int J Obes Relat Metab Disord 2004, 28(1):176-179.

9. Chambon P: A decade of molecular biology of retinoic acid receptors. Faseb J 1996, 10(9):940-954.

10. Evans TR, Kaye SB: Retinoids: present role and future potential. Br J Cancer 1999, 80(1-2):1-8.

11. Petkovich M, Brand NJ, Krust A, Chambon P: A human retinoic acid receptor which belongs to the family of nuclear receptors. Nature 1987, 330(6147):444-450.

12. Giguere $V$, Ong ES, Segui $P$, Evans RM: Identification of a receptor for the morphogen retinoic acid. Nature 1987, 330(6149):624-629.

13. Shaw N, Elholm M, Noy N: Retinoic acid is a high affinity selective ligand for the peroxisome proliferator-activated receptor beta/delta. J Biol Chem 2003, 278(43):41589-41592

14. Zhou XE, Suino-Powell KM, Xu Y, Chan CW, Tanabe O, Kruse SW, Reynolds R, Engel JD, Xu HE: The orphan nuclear receptor TR4 is a vitamin A-activated nuclear receptor. J Biol Chem 2011, 286(4):2877-2885.

15. Kruse SW, Suino-Powell K, Zhou XE, Kretschman JE, Reynolds R, Vonrhein C, Xu Y, Wang L, Tsai SY, Tsai MJ, et al: Identification of COUP-TFII orphan nuclear receptor as a retinoic acid-activated receptor. PLOS Biol 2008, 6(9):e227.

16. Berry DC, Noy N: All-trans-retinoic acid represses obesity and insulin resistance by activating both peroxisome proliferation-activated receptor beta/delta and retinoic acid receptor. Mol Cell Biol 2009, 29(12):3286-3296.

17. Bonet ML, Oliver J, Pico C, Felipe F, Ribot J, Cinti S, Palou A: Opposite effects of feeding a vitamin A-deficient diet and retinoic acid treatment on brown adipose tissue uncoupling protein 1 (UCP1), UCP2 and leptin expression. J Endocrinol 2000, 166(3):511-517.
18. Bastien J, Rochette-Egly C: Nuclear retinoid receptors and the transcription of retinoid-target genes. Gene 2004, 328:1-16.

19. Schwarz EJ, Reginato MJ, Shao D, Krakow SL, Lazar MA: Retinoic acid blocks adipogenesis by inhibiting C/EBPbeta-mediated transcription. Mo/ Cell Biol 1997, 17(3):1552-1561.

20. Xue JC, Schwarz EJ, Chawla A, Lazar MA: Distinct stages in adipogenesis revealed by retinoid inhibition of differentiation after induction of PPARgamma. Mol Cell Biol 1996, 16(4):1567-1575.

21. Berry DC, DeSantis D, Soltanian H, Croniger CM, Noy N: Retinoic acid upregulates preadipocyte genes to block adipogenesis and suppress diet-induced obesity. Diabetes 2012, 61(5):1112-1121.

22. Safonova I, Reichert U, Shroot B, Ailhaud G, Grimaldi P: Fatty acids and retinoids act synergistically on adipose cell differentiation. Biochem Biophys Res Commun 1994, 204(2):498-504

23. Marchildon F, St-Louis C, Akter R, Roodman V, Wiper-Bergeron NL: Transcription factor Smad3 is required for the inhibition of adipogenesis by retinoic acid. J Biol Chem 2010, 285(17):13274-13284.

24. Alvarez R, de Andres J, Yubero P, Vinas O, Mampel T, Iglesias R, Giralt M, Villarroya $F$ : A novel regulatory pathway of brown fat thermogenesis. Retinoic acid is a transcriptional activator of the mitochondrial uncoupling protein gene. J Bio/ Chem 1995, 270(10):5666-5673.

25. Rabelo R, Reyes C, Schifman A, Silva JE: A complex retinoic acid response element in the uncoupling protein gene defines a novel role for retinoids in thermogenesis. Endocrinology 1996, 137(8):3488-3496.

26. Sears IB, MacGinnitie MA, Kovacs LG, Graves RA: Differentiation-dependent expression of the brown adipocyte uncoupling protein gene: regulation by peroxisome proliferator-activated receptor gamma. Mol Cell Biol 1996, 16(7):3410-3419.

27. del Mar Gonzalez-Barroso M, Pecqueur C, Gelly C, Sanchis D, Alves-Guerra MC, Bouillaud F, Ricquier D, Cassard-Doulcier AM: Transcriptional activation of the human ucp 1 gene in a rodent cell line. Synergism of retinoids, isoproterenol, and thiazolidinedione is mediated by a multipartite response element. J Biol Chem 2000, 275(41):31722-31732.

28. Puigserver $\mathrm{P}$, Vazquez $\mathrm{F}$, Bonet $\mathrm{ML}$, Pico $\mathrm{C}$, Palou $\mathrm{A}$ : In vitro and in vivo induction of brown adipocyte uncoupling protein (thermogenin) by retinoic acid. Biochem J 1996, 317(Pt 3):827-833.

29. Teruel T, Hernandez R, Benito M, Lorenzo M: Rosiglitazone and retinoic acid induce uncoupling protein-1 (UCP-1) in a p38 mitogen-activated protein kinase-dependent manner in fetal primary brown adipocytes. J Biol Chem 2003, 278(1):263-269.

30. Mercader J, Madsen L, Felipe F, Palou A, Kristiansen K, Bonet ML: All-trans retinoic acid increases oxidative metabolism in mature adipocytes. Cell Physiol Biochem 2007, 20(6):1061-1072.

31. Mercader J, Palou A, Bonet ML: Induction of uncoupling protein-1 in mouse embryonic fibroblast-derived adipocytes by retinoic acid. Obesity (Silver Spring) 2010, 18(4):655-662

32. Mercader J, Ribot J, Murano I, Felipe F, Cinti S, Bonet ML, Palou A: Remodeling of white adipose tissue after retinoic acid administration in mice. Endocrinology 2006, 147(11):5325-5332.

33. de The $H$, Marchio A, Tiollais P, Dejean A: Differential expression and ligand regulation of the retinoic acid receptor alpha and beta genes. Embo J 1989, 8(2):429-433.

34. Martin CA, Ziegler LM, Napoli JL: Retinoic acid, dibutyryl-cAMP, and differentiation affect the expression of retinoic acid receptors in F9 cells. Proc Natl Acad Sci USA 1990, 87(12):4804-4808.

35. Hansen JB, Jorgensen C, Petersen RK, Hallenborg P, De Matteis R, Boye HA, Petrovic N, Enerback S, Nedergaard J, Cinti S, et al: Retinoblastoma protein functions as a molecular switch determining white versus brown adipocyte differentiation. Proc Natl Acad Sci USA 2004, 101(12):4112-4117.

36. Reznikoff CA, Brankow DW, Heidelberger C: Establishment and characterization of a cloned line of $\mathrm{C} 3 \mathrm{H}$ mouse embryo cells sensitive to postconfluence inhibition of division. Cancer Res 1973, 33(12):3231-3238.

37. Charton J, Deprez-Poulain R, Hennuyer N, Tailleux A, Staels B, Deprez B: Novel non-carboxylic acid retinoids: 1,2,4-oxadiazol-5-one derivatives. Bioorg Med Chem Lett 2009, 19(2):489-492.

38. Schug TT, Berry DC, Shaw NS, Travis SN, Noy N: Opposing effects of retinoic acid on cell growth result from alternate activation of two different nuclear receptors. Cell 2007, 129(4):723-733.

39. Wang YX, Lee CH, Tiep S, Yu RT, Ham J, Kang H, Evans RM: Peroxisomeproliferator-activated receptor delta activates fat metabolism to prevent obesity. Cell 2003, 113(2):159-170. 
40. Pan D, Fujimoto M, Lopes A, Wang YX: Twist-1 is a PPARdelta-inducible, negative-feedback regulator of PGC-1alpha in brown fat metabolism. Cell 2009, 137(1):73-86.

41. Vosper H, Patel L, Graham TL, Khoudoli GA, Hill A, Macphee CH, Pinto I, Smith SA, Suckling KE, Wolf CR, et al: The peroxisome proliferatoractivated receptor delta promotes lipid accumulation in human macrophages. J Biol Chem 2001, 276(47):44258-44265.

42. Puigserver $P$, Wu Z, Park CW, Graves R, Wright M, Spiegelman BM: A cold-inducible coactivator of nuclear receptors linked to adaptive thermogenesis. Cell 1998, 92(6):829-839.

43. Uldry M, Yang W, St-Pierre J, Lin J, Seale P, Spiegelman BM: Complementary action of the PGC-1 coactivators in mitochondrial biogenesis and brown fat differentiation. Cell Metab 2006, 3(5):333-341.

44. Wabitsch M, Brenner RE, Melzner I, Braun M, Moller P, Heinze E, Debatin KM, Hauner $\mathrm{H}$ : Characterization of a human preadipocyte cell strain with high capacity for adipose differentiation. Int J Obes Relat Metab Disord 2001, 25(1):8-15.

45. Rodriguez AM, Pisani D, Dechesne CA, Turc-Carel C, Kurzenne JY, Wdziekonski B, Villageois A, Bagnis C, Breittmayer JP, Groux H, et al: Transplantation of a multipotent cell population from human adipose tissue induces dystrophin expression in the immunocompetent $\mathrm{mdx}$ mouse. J Exp Med 2005, 201(9):1397-1405.

46. Zaragosi LE, Ailhaud G, Dani C: Autocrine fibroblast growth factor 2 signaling is critical for self-renewal of human multipotent adiposederived stem cells. Stem Cells 2006, 24(11):2412-2419.

47. Villarroya F, Giralt M, Iglesias R: Retinoids and adipose tissues: metabolism, cell differentiation and gene expression. Int J Obes Relat Metab Disord 1999, 23(1):1-6.

48. Bonet ML, Ribot J, Palou A: Lipid metabolism in mammalian tissues and its control by retinoic acid. Biochim Biophys Acta 2012, 1821(1):177-189.

49. Ribot J, Felipe F, Bonet ML, Palou A: Retinoic acid administration and vitamin $A$ status modulate retinoid $X$ receptor alpha and retinoic acid receptor alpha levels in mouse brown adipose tissue. Mol Cell Biochem 2004, 266(1-2):25-30.

50. Kumar MV, Scarpace PJ: Differential effects of retinoic acid on uncoupling protein-1 and leptin gene expression. J Endocrinol 1998, 157(2):237-243.

51. Larose M, Cassard-Doulcier AM, Fleury C, Serra F, Champigny O, Bouillaud F, Ricquier D: Essential cis-acting elements in rat uncoupling protein gene are in an enhancer containing a complex retinoic acid response domain. J Biol Chem 1996, 271(49):31533-31542.

52. Alvarez R, Checa M, Brun S, Vinas O, Mampel T, Iglesias R, Giralt M, Villarroya F: Both retinoic-acid-receptor- and retinoid-X-receptor-dependent signalling pathways mediate the induction of the brown-adipose-tissueuncoupling-protein-1 gene by retinoids. Biochem J 2000, 345(Pt 1):91-97.

53. Hernandez A, de Mena RM, Martin E, Obregon MJ: Differences in the response of UCP1 mRNA to hormonal stimulation between rat and mouse primary cultures of brown adipocytes. Cell Physiol Biochem 2011, 28(5):969-980.

54. Lehr L, Canola K, Leger B, Giacobino JP: Differentiation and characterization in primary culture of white adipose tissue brown adipocyte-like cells. Int J Obes (Lond) 2009, 33(6):680-686.

55. Berry DC, Noy N: Signaling by vitamin A and retinol-binding protein in regulation of insulin responses and lipid homeostasis. Biochim Biophys Acta 2012, 1821(1):168-176.

56. Murholm M, Dixen K, Qvortrup K, Hansen LH, Amri EZ, Madsen L, Barbatelli G, Quistorff B, Hansen JB: Dynamic regulation of genes involved in mitochondrial DNA replication and transcription during mouse brown fat cell differentiation and recruitment. PLoS One 2009, 4(12):e8458.

57. Murholm M, Dixen K, Hansen JB: Ras signalling regulates differentiation and UCP1 expression in models of brown adipogenesis. Biochim Biophys Acta 2010, 1800(6):619-627.

58. Elabd C, Chiellini C, Carmona M, Galitzky J, Cochet O, Petersen R, Penicaud L, Kristiansen K, Bouloumie A, Casteilla L, et al: Human multipotent adipose-derived stem cells differentiate into functional brown adipocytes. Stem cells 2009, 27(11):2753-2760.

59. Pisani DF, Djedaini M, Beranger GE, Elabd C, Scheideler M, Ailhaud G, Amri EZ: Differentiation of human adipose-derived stem cells into "Brite" (brown-in-white) adipocytes. Frontiers Endocrinol 2011, 2:87.

60. Bordicchia M, Liu D, Amri EZ, Ailhaud G, Dessi-Fulgheri P, Zhang C, Takahashi N, Sarzani R, Collins S: Cardiac natriuretic peptides act via p38 MAPK to induce the brown fat thermogenic program in mouse and human adipocytes. J Clin Investig 2012, 122(3):1022-1036.
61. Tews D, Fischer-Posovszky P, Fromme T, Klingenspor M, Fischer J, Ruther U, Marienfeld R, Barth T, Moller P, Debatin K, et al: FTO deficiency induces UCP-1 expression and mitochondrial uncoupling in adipocytes. Endocrinology 2013, 154(9):3141-3151.

62. Tiraby C, Tavernier G, Lefort C, Larrouy D, Bouillaud F, Ricquier D, Langin D: Acquirement of brown fat cell features by human white adipocytes. J Biol Chem 2003, 278(35):33370-33376.

63. Green HKO: Sublines of mouse 3T3 cells that accumulate lipid. Cell 1974, $1: 113-116$.

64. Hansen JB, Petersen RK, Larsen BM, Bartkova J, Alsner J, Kristiansen K: Activation of peroxisome proliferator-activated receptor gamma bypasses the function of the retinoblastoma protein in adipocyte differentiation. J Biol Chem 1999, 274(4):2386-2393.

doi:10.1186/1471-2121-14-41

Cite this article as: Murholm et al:: Retinoic acid has different effects on UCP1 expression in mouse and human adipocytes. BMC Cell Biology 2013 14:41.

\section{Submit your next manuscript to BioMed Central and take full advantage of:}

- Convenient online submission

- Thorough peer review

- No space constraints or color figure charges

- Immediate publication on acceptance

- Inclusion in PubMed, CAS, Scopus and Google Scholar

- Research which is freely available for redistribution 